\title{
Analysis of the Influence of New Usages on the State of Conservation of Historical Buildings through Microclimate Characterization
}

\author{
Mariana Estima Silva ${ }^{1}$, Ariela da Silva Torres ${ }^{1}$, Eduardo Grala da Cunha ${ }^{2}$ and Isabel Tourinho Salamoni ${ }^{2}$ \\ 1. Postgraduate Program in Architecture and Urbanism, Federal Institute of Science and Technological Education/Federal \\ University of Pelotas, Pelotas 96010-020, Brazil \\ 2. Laboratory of Comfort and Energy Efficiency, Faculty of Architecture and Urbanism, Federal University of Pelotas, Pelotas \\ 96010-020, Brazil
}

\begin{abstract}
Recycling is an alternative for preserving historical heritage buildings. Through such process, buildings are occupied by new usages that assure they are not abandoned. However, conservation issues, like pathological manifestations by filamentous fungi, are common even in buildings receiving new uses. Thus, it is extremely important to know the microclimate behavior of these buildings and analyze if there are usages that favor the appearance of filamentous fungi or not. This study aims to verify if new usages modify the microclimate in historical buildings and if such possible change favors the appearance of pathological manifestations by filamentous fungi in some specific use. To achieve the results, three buildings that have gone through recycling processes were chosen in the city of Pelotas, in Southernmost Brazil. The city possesses a large number of buildings with historical value and its climate conditions are propitious for appearance of filamentous fungi. For 12 months, microclimate was monitored, the environments modus operandi was characterized and there was a survey on the pathological manifestations by filamentous fungi in the three buildings with two different uses: administration offices and exhibition rooms. Conclusion was that usages that allow natural ventilation and lighting favor conservation, which is what happens in the ones used as administration offices. Besides that, it was noticed that the construction system also influences, since buildings with a high cellar that is being used did not present filamentous fungi, which also shows the influence of ascending humidity on the appearance of such pathological manifestations.
\end{abstract}

Key words: Historical buildings, new usages, microclimate, pathological manifestations.

\section{Introduction}

To ensure historical buildings are used is an alternative for their preservation. So, corrective and preventive measures can be adopted before the construction gets to poor conditions of conservation. However, over the years, the original use of buildings with historical value is often no longer needed in society, making usage difficult [1].

Recycling processes, or retrofit, of historical constructions comes up to face this problem. It is an adaptation for new uses that keeps the formal

Corresponding author: Eduardo Grala da Cunha, professor, research fields: energy efficiency and thermal performance. E-mail: eduardogralacunha@yahoo.com.br. characteristics of the buildings and ensures they are used [2].

Pelotas presents a large number of buildings with historical value, mainly from the 19th century, when the city economy experienced a very important period. Nowadays, Pelotas has 19 legally protected heritage buildings and approximately 1,700 buildings listed in the city heritage inventory [3]. Many of those suffer from the lack of conservation measures and their original usages have already been changed. This way, studies on conservation of historical heritage buildings are very important for the city. In Fig. 1, an illustration shows Pelotas' historical centre, with some of these constructions. 


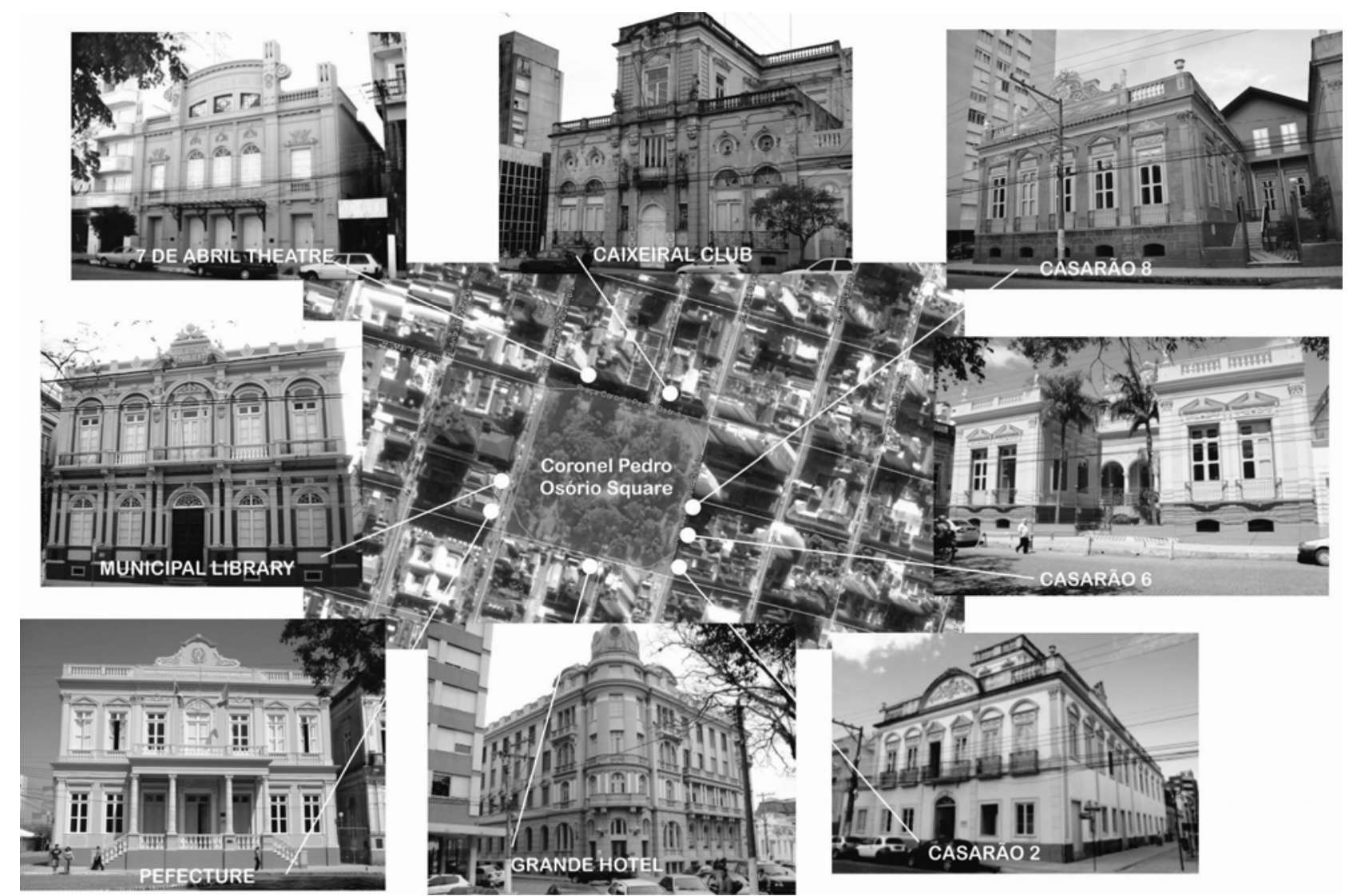

Fig. 1 Images of Pelotas' historical centre (around Coronel Pedro Osório Square).

Source: the authors.

\subsection{New Usages of Historical Buildings}

Many authors have been approaching the theme of new usages of historical buildings in several aspects. Camuffo et al. [4] worked on the impacts over the state of conservation of historical buildings. They analyzed a medieval construction in Italy that received a new use, as an auditorium. As causes of impact, they considered the artificial lighting and heating systems, as well as the increase in the number of users inside the buildings. They realized that heating systems in historical buildings are difficult to control, for they cause unbalance between temperature and relative humidity and hamper the conservation of construction materials. This way, these authors have found difficulty in keeping the environment comfortable for users without impairing the building's conservation state.

The influence of purposive modification of internal microclimate may directly affect the state of conservation of historical constructions. A study by Silva and Henriques [5] in a church with historical value in Portugal substantiates such data. These authors state that changing the historical microclimate, to which construction materials are already acclimatized, can cause serious harm to buildings.

Aykall et al. [6] have carried out studies on the quality of lighting for the new use needs in historical buildings in Turkey. In their study, they analyzed the new uses for administration offices and exhibition rooms. They concluded that the buildings did not present good lighting conditions for the new uses, although they did for the original one.

Guerra et al. [7] worked on monitoring internal microclimate in a building in Pelotas, aiming to relate it to the appearance of filamentous fungi. The building has been recycled for hosting exhibition rooms. The authors state that due to lack of knowledge about 
these constructions' thermal and hygroscopic behavior, alternatives of natural ventilation and lighting are often empirically used. Such changes in the spaces' modus operandi favors biodeterioration.

Based on the works above, it is necessary to consider, when choosing new usages, the changes that they will cause in internal microclimate. The modification of environmental parameters can cause the appearance of filamentous fungi, cracks and other pathological manifestations in the constructions. It is also necessary to verify if the building offers ideal comfort conditions for the new usages and to know the conditions that favor the emergence of pathological manifestations.

\subsection{The Influence of Microclimate in the Appearance of Pathological Manifestations}

Constructions are expected to get old, since they are subject to the actions of time. However, there are several influences that accelerate or retard this process, such as: weather, quality of materials, frequent maintenance [8]. When buildings suffer from some kind of performance drop, they present symptoms, which are called pathological manifestations [9].

The most recurrent cause of appearance of pathological manifestations is the presence of water [10-13]. In a work carried out by Lourenço et al. [13] in the historical centre of a city in Portugal, they found that the presence of humidity, along with inadequate conditions of exposure to natural light and ventilation, were the main causes of deterioration in the constructions that were analyzed. They also found that the combination of such environmental effects and the lack of maintenance can be considered as the great responsible for damages in historical buildings.

Pelotas is characterized by humid subtropical climate, with warm summers and mild rainy winters. The average annual temperature is $17.8{ }^{\circ} \mathrm{C}$ and the mean of relative humidity is $80.7 \%$ in the year [14]. This way, the appearance of pathological manifestations related to the presence of humidity is common in the city. That shows the importance of studies on the influence of environmental parameters in conservation of historical buildings.

Air temperature alone is not the major cause of material damage. Nonetheless, a great temperature variation during the day can favor the appearance of pathological manifestations like expansion or dryness of materials. Besides that, temperature is always related to humidity. Relative humidity is an important accelerator of the increase of biodeterioration sources. Its high levels and daily oscillation are extremely harmful for materials $[15,16]$.

The appearance of filamentous fungi is related to the conditions considered as ideal for temperature and humidity and to the nutrients available on the surface of constructions, like dust. An internal microclimate of low temperatures and high levels of relative humidity favors the appearance of pathological manifestations related to filamentous fungi [17, 18]. When there is not much air change, with natural ventilation, and spaces have low incidence of solar radiation, damages may become more serious, as concluded by Guerra et al. [18] in an analysis through computer simulation of filamentous fungi in a 19th century building in Pelotas.

Sterflinger [19] states that, to control proliferation of filamentous fungi in construction materials, it is important that the environment's relative humidity should be at a maximum of 55\%. Periodical cleaning must also be considered to avoid accumulation of nutrients on surfaces. Therefore, it is possible to notice that the kind of use of a building, as well as climatization systems, may directly influence the appearance of pathological manifestations by filamentous fungi and consequently alter its conservation state.

\section{Objective}

The objective of this work is to verify influence of new usages in microclimate changes in historical buildings and the impact of such changes in the 
appearance of pathological manifestations related to filamentous fungi. Analysis was made at the Casarões (old mansions) numbered 2, 6 and 8 in the city of Pelotas, RS, Brazil.

\section{Method}

Research was divided into four stages. At first, we chose the new usages and the environments to be analyzed in each one of the buildings, to characterize the object of the study. The second stage was monitoring internal microclimate in the environments and then have environmental parameters of temperature and relative humidity.

After, we characterized the users' modus operandi regarding the spaces, by observing and taking notes, aiming to relate using modes to the new usages.

The last stage was a survey on pathological manifestations related to filamentous fungi in all environments.

\subsection{Characterization of the Object of Study}

The three buildings in the case study were built in the 19th century and their ensemble was registered by the National Historic and Artistic Heritage Institute, highlighting their historical value [3]. They all present the same construction system: masonry of solid bricks and lime-based plaster. Because it was built before the others, Casarão 2 does not have a high cellar, which means its ground floor is not ventilated like the others. A common feature at the three houses is the great thickness of their walls': 60 to $90 \mathrm{~cm}$ in the external walls, providing high thermal inertia. The three mansions are presented in Figs. 2-4.

The Casarões went through processes of recycling, to host new usages as Cultural Centers and receive arts exhibitions. Mansion 2 also became an administration office, as the City Culture Department, on the second floor. For this, analysis adopted the administrative usage located on the second floor in all the houses. For the exhibition room usage, analysis adopted the environment of the ground floor. This way, we tried to reduce the number of variables and make comparison possible, with environments of the same usage on the same floor. Other than this, the environments that were analyzed have the same solar orientations, south and west. House 6 is not being used at the moment. Although it has been recycled for the same uses, it was closed during the survey. So, it was possible to analyze different uses inside the same building and of the same use in different buildings, and also to compare characterization of a closed building (Table 1).

\subsection{Microclimate Monitoring}

For characterizing microclimates in the environments studied, we used temperature and relative

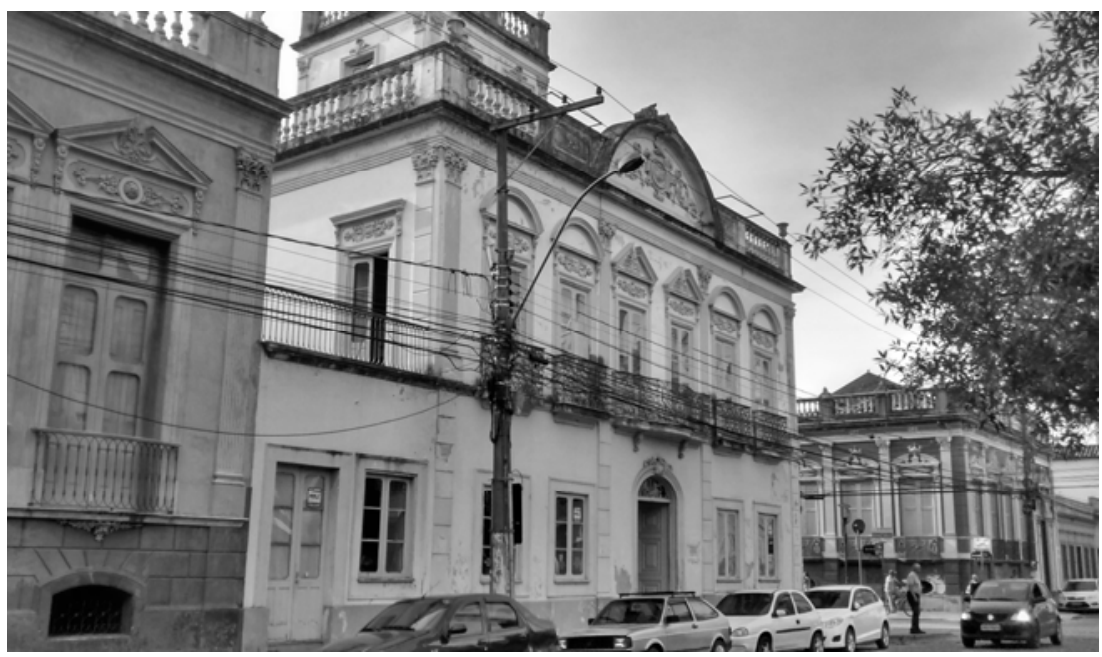

Fig. 2 Casarão 2.

Source: the authors. 

Historical Buildings through Microclimate Characterization

Fig. 3 Casarão 6.

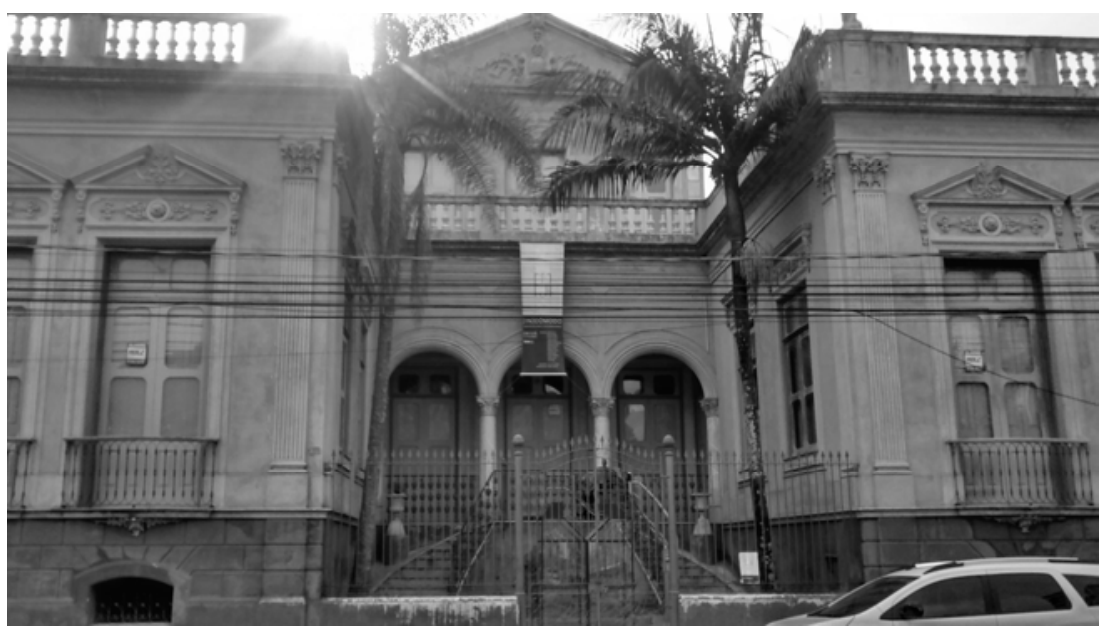

Source: the authors.

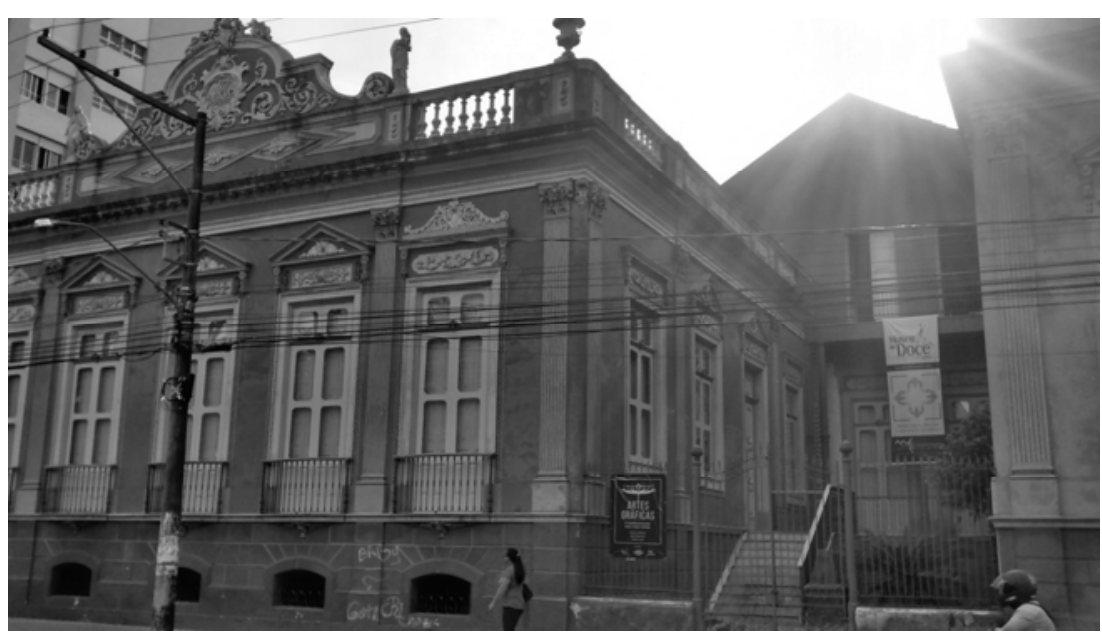

Fig. 4 Casarão 8.

Source: the authors.

Table 1 Characterization of the object of study.

\begin{tabular}{llll}
\hline Building & Cellar & Ground floor & Second floor \\
\hline Casarão 2 & No cellar & Exhibition room & Administration offices \\
Casarão 6 & Cellar & Not used & Not used \\
Casarão 8 & Cellar & Exhibition room & Administration offices \\
\hline
\end{tabular}

humidity sensors, model HOBO H8 RH/Temp Data Logger. Equipment was tested in a double thermal box for 72 hours, for posterior analysis and accuracy checking, according to manufacturer specifications [7].

After testing stage, HOBOs were programmed with software BoxCar Pro 4 for collecting data on temperature and relative humidity every hour. Then, sensors were installed in each environment studied, in a total of six sensors. We used the same height from the floor, the same installation and the same sensor position in all the houses, according to the methodology by Guerra et al. [7]. Each month, equipment were discharged for collecting data, through the same software, and batteries were replaced when necessary.

Monitoring started in December 2015 and finished in November 2016, completing a total of 12 months.

This way, it was possible to characterize the environments' behavior through each season of the 
year. For this research, we opted to work with summer and winter, with an intention to characterize and compare microclimate during the year's extremes.

\subsection{Characterization of the Environments' Modus Operandi}

As the three buildings analyzed follow the same construction system and then environments chosen have the same solar orientations-south and west, it was necessary to characterize the operation of the spaces related to the new usages.

This way, survey was carried out about the way users use each environment.

Survey was made regarding the modes of operating windows in the spaces dedicated to exhibition rooms, as well as in the ones used for administration offices. There was also a qualitative survey about the internal load of heat and humidity, like number of users and equipment inside the environments.

Features related to construction were also researched, through presence or absence of ascending humidity sources, as the exhibition rooms environments are always located on the ground floor and the administration offices ones on the second floor, bringing up some differences regarding such features.

All the variables analyzed can be seen in Table 2 .

\subsection{Survey on the Pathological Manifestations by} Filamentous Fungi

The survey on the pathological manifestations related to the presence of filamentous fungi was carried out according to Lichtenstein's [9] methodology. We made several inspections in the environments, by visual means and photographic registers every three months, coinciding with the changes of the seasons. This made it possible to analyze the influence of each season's microclimate in the appearance, disappearance or aggravation of the incidence of filamentous fungi. After survey, identification sheets were made for each manifestation that was found.

\section{Analysis of Results}

Survey was made the same way in the three buildings that were studied. For analysis of results, we opted for looking at data in the winter's coldest week day and in the summer's warmest one, analyzing the buildings with equipment being used, windows open and presence of users in the environments. To look at the influence of these variables in the results, we also opted to analyze the winter's coldest weekend day and the summer's warmest one, when buildings are not used.

This way, results were obtained for the houses in different ways of using them, according to Table 3.

\subsection{Analysis of Results on a Week Day}

With Tables 4 and 5, it is possible to notice that in week days in summer internal temperatures in environments used as administration offices began to rise only by the end of the morning in all buildings, due to the walls' great thickness.

In winter, temperatures did not vary significantly, the same way they did not rise along the day outside either, as seen on Figs. 5 and 6.

It was also seen, through daily thermal and hygroscopic behavior of the environments, that Mansion

Table 2 Variables found in each environment.

\begin{tabular}{|c|c|c|c|}
\hline \multicolumn{4}{|l|}{ Analyzed variables } \\
\hline \multicolumn{4}{|c|}{ Presence of natural ventilation } \\
\hline \multicolumn{4}{|c|}{ Incidence of solar radiation } \\
\hline \multicolumn{4}{|c|}{ Sources of ascending humidity } \\
\hline \multicolumn{4}{|c|}{ Sources of humidity from the own environment } \\
\hline \multicolumn{4}{|c|}{ Table 3 Conditions of use of the buildings. } \\
\hline \multirow{2}{*}{ Use } & \multirow{2}{*}{ Environments } & \multicolumn{2}{|c|}{ Summer and winter } \\
\hline & & Weekday & Weekend \\
\hline \multirow{3}{*}{$\begin{array}{l}\text { Administration } \\
\text { offices }\end{array}$} & Casarão 2 & Used & Closed \\
\hline & Casarão 6 & Closed & Closed \\
\hline & Casarão 8 & Used & Closed \\
\hline \multirow{3}{*}{ Exhibition rooms } & Casarão 2 & Used & Closed \\
\hline & Casarão 6 & Closed & Closed \\
\hline & Casarão 8 & Used & Closed \\
\hline
\end{tabular}


Table 4 Results for a week day in summer in administration usage-qualitative analysis

\begin{tabular}{llll}
\hline Variables & Casarão 2 & Casarão 6 & Casarão 8 \\
\hline Natural ventilation & Existent & Inexistent & Existent \\
Air temperature & Lower & Intermediate & Higher \\
Relative humidity & Intermediate & Higher & Lower \\
Humidity sources & Existent & Inexistent & Existent \\
Ascending humidity & Inexistent & Inexistent & Inexistent \\
Solar radiation & Existent & Inexistent & Existent \\
Pathological manifestations by filamentous fungi & Lower & Inexistent & Inexistent \\
\hline
\end{tabular}

Table 5 Results for a week day in winter in administration usage-qualitative analysis.

\begin{tabular}{llll}
\hline Variables & Casarão 2 & Casarão 6 & Casarão 8 \\
\hline Natural ventilation & Existent & Inexistent & Existent \\
Air temperature & Higher & Lower & Intermediate \\
Relative humidity & Lower & Higher & Intermediate \\
Humidity sources & Existent & Inexistent & Existent \\
Ascending humidity & Inexistent & Inexistent & Inexistent \\
Solar radiation & Existent & Inexistent & Existent \\
Pathological manifestations by filamentous fungi & Lower & Higher & Inexistent \\
\hline
\end{tabular}

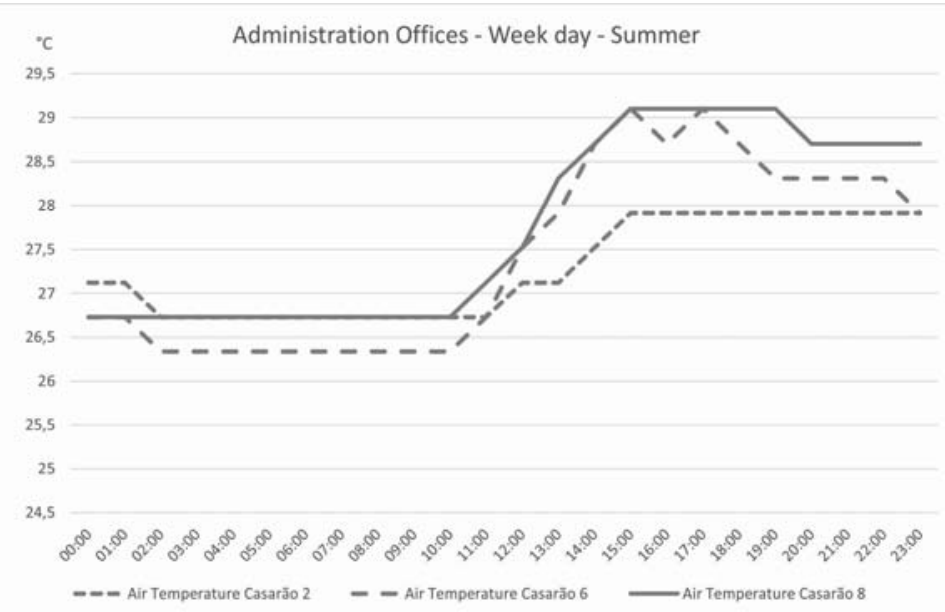

Fig. 5 Thermal behavior on a summer week day-administration offices.

Source: the authors.

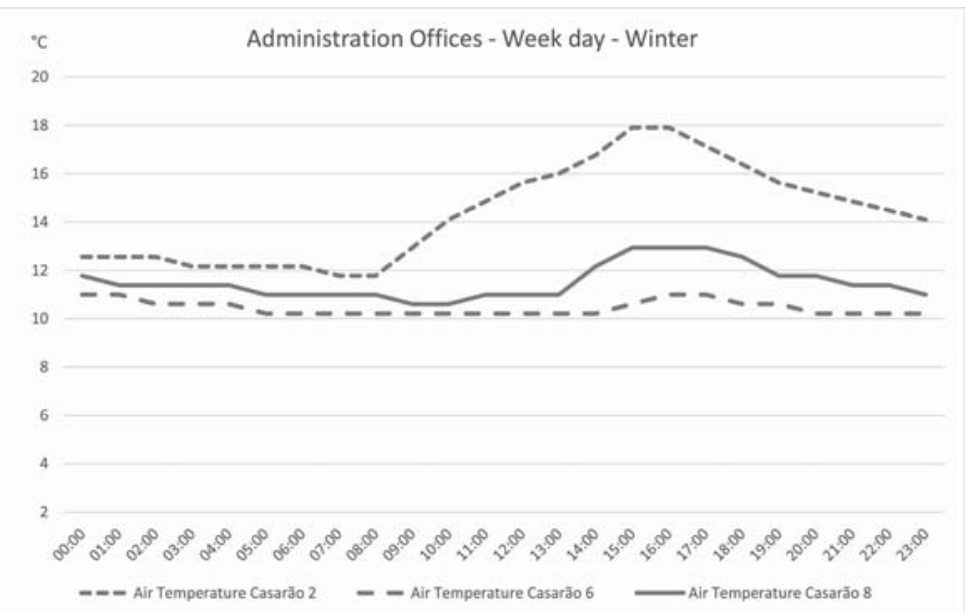

Fig. 6 Thermal behavior on a winter week day-administration offices.

Source: the authors. 
Number 2 presented a different curve from the others. In this environment, air temperature values were milder than in the others during summer, since users operated windows searching to block solar incidence and thus, the heat inside. Curve was also different during winter, since there were more users compared to the other buildings and solar incidence was no longer controlled, increasing the production of heat inside the environment. Casarão 8, even having users, has more depth regarding windows, allowing them to be open without causing thermal discomfort.

Besides these results, it was also noticed that the unused building, Casarão 6, presented higher values for relative humidity in both periods-Figs. 7 and 8 . In summer, there were no pathological manifestations related to filamentous fungi. On the other hand, in winter, there was a higher incidence of filamentous fungi than in the other buildings. In the administrative environment of House Number 2, incidence of filamentous fungi was low in both periods. In Casarão 8 , there were no pathological manifestations.

In a week day with the exhibition room usage, environments of all the buildings presented the same behavior of the ones used as administration offices, regarding thermal delay-Tables 6 and 7. That means that, in the same way, in summer, internal temperatures began to rise by the end of the morning and in winter, they did not change in a significant way-Figs. 9 and 10. In this use, curves are equivalent and so is the hygroscopic behavior-Figs. 11 and 12-as exhibitions rooms do not present internal sources of humidity. Even though they are

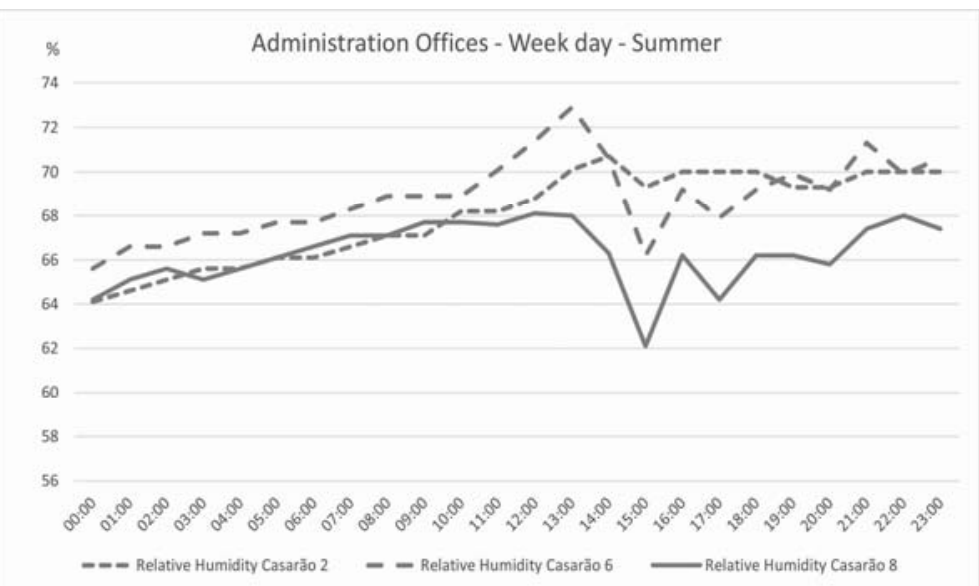

Fig. 7 Hygroscopic behavior on a summer week day—administration offices. Source: the authors.

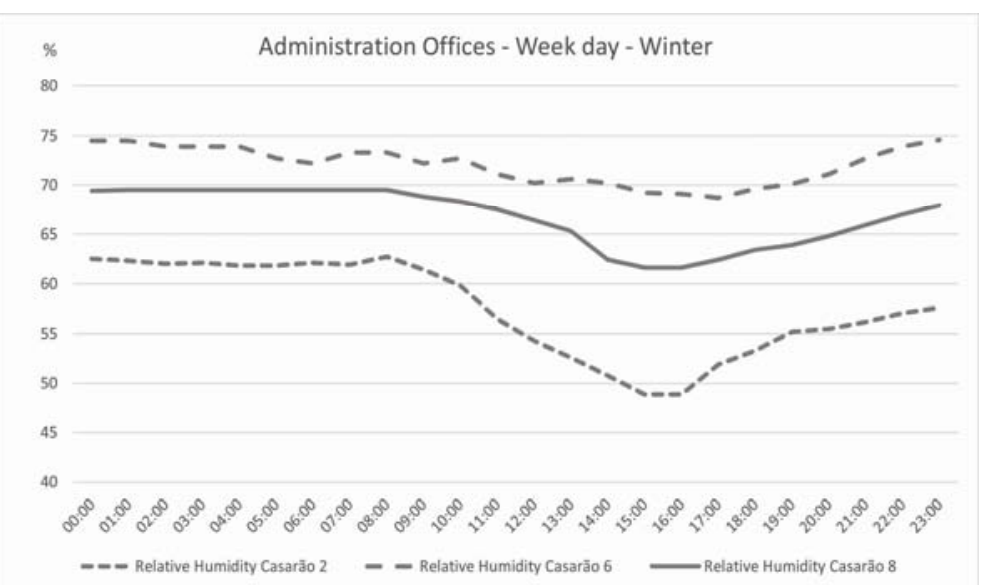

Fig. 8 Hygroscopic behavior on a winter week day-administration offices.

Source: the authors. 
Table 6 Results for a week day in summer in exhibition room usage-qualitative analysis.

\begin{tabular}{llll}
\hline Variables & Casarão 2 & Casarão 6 & Casarão 8 \\
\hline Natural ventilation & Reduced & Inexistent & Reduced \\
Air temperature & Lower & Intermediate & Higher \\
Relative humidity & Higher & Intermediate & Lower \\
Humidity sources & Reduced & Inexistent & Reduced \\
Ascending humidity & Existent & Inexistent & Inexistent \\
Solar radiation & Reduced & Inexistent & Reduced \\
Pathological manifestations by filamentous fungi & High & Inexistent & Inexistent \\
\hline
\end{tabular}

Table 7 Results for a week day in winter in exhibition room usage—qualitative analysis.

\begin{tabular}{llll}
\hline Variables & Casarão 2 & Casarão 6 & Casarão 8 \\
\hline Natural ventilation & Reduced & Inexistent & Reduced \\
Air temperature & Higher & Lower & Intermediate \\
Relative humidity & Lower & Higher & Intermediate \\
Humidity sources & Reduced & Inexistent & Reduced \\
Ascending humidity & Existent & Inexistent & Inexistent \\
Solar radiation & Reduced & Inexistent & Reduced \\
Pathological manifestations by filamentous fungi & Higher & Lower & Inexistent \\
\hline
\end{tabular}

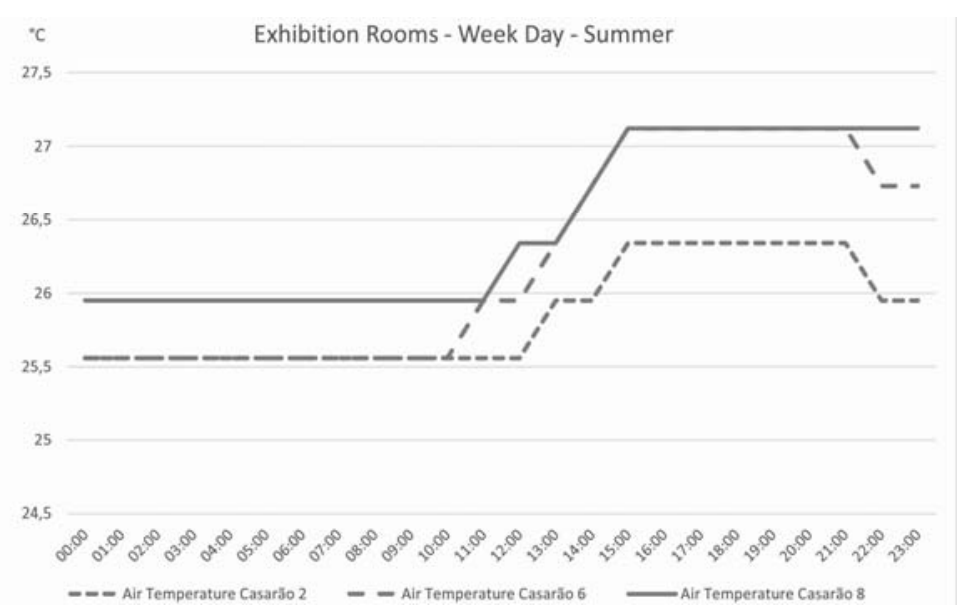

Fig. 9 Thermal behavior on a summer week day-exhibition rooms.

Source: the authors.

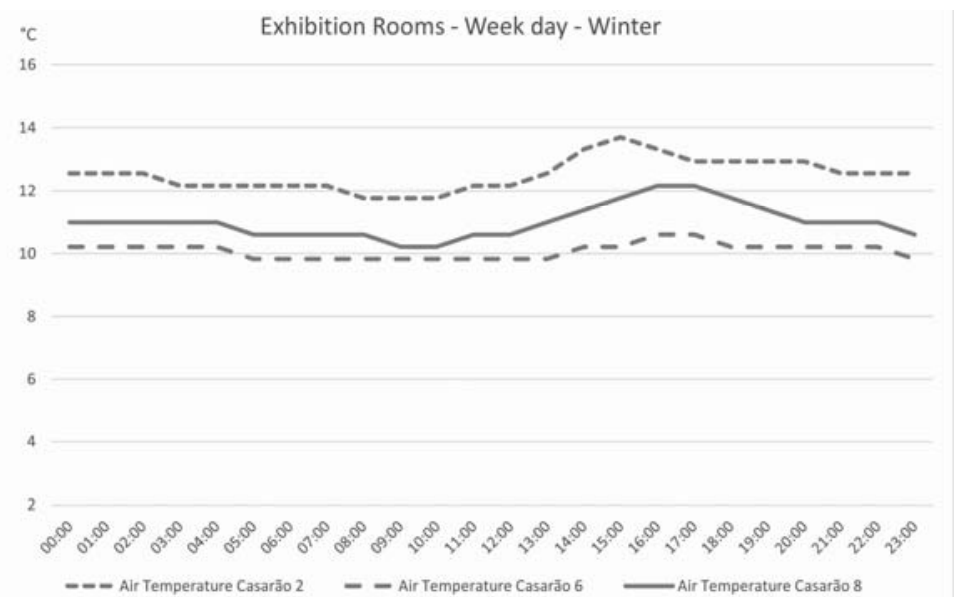

Fig. 10 Thermal behavior on a winter week day-exhibition rooms.

Source: the authors. 


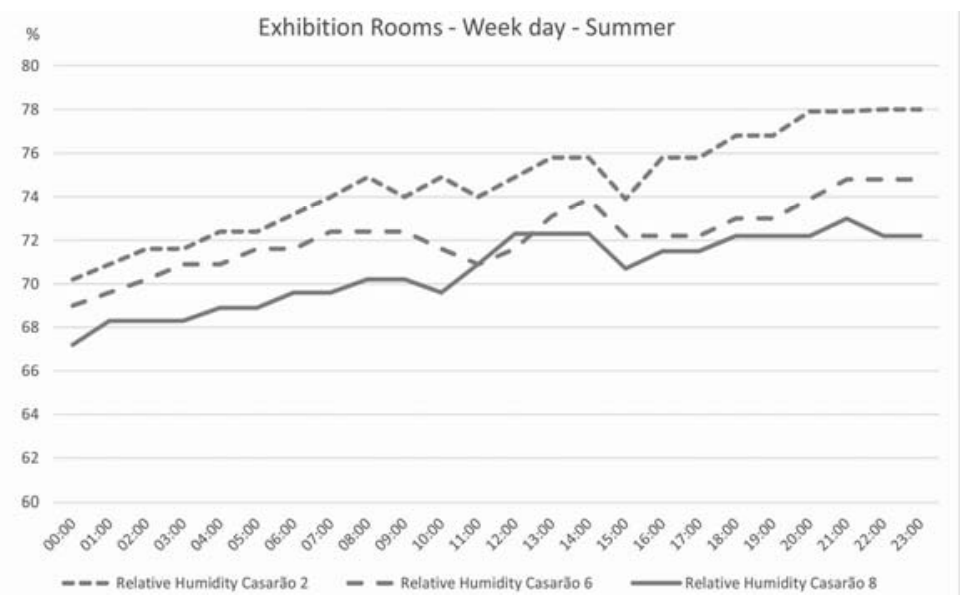

Fig. 11 Hygroscopic behavior on a summer week day-exhibition rooms.

Source: the authors.

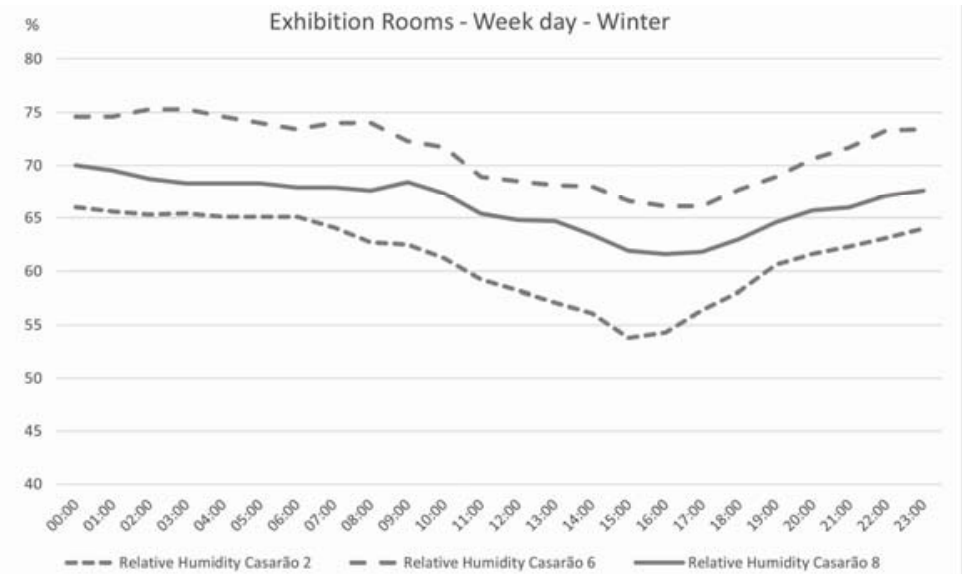

Fig. 12 Hygroscopic behavior on a winter week day-exhibition rooms.

Source: the authors.

equivalent, the highest internal temperature levels in summer were registered in Casarão 8, while in winter, the highest values were found in Casarão 2. This happened due to the thermal changes of the construction in contact with the ground. The environment in Casarão 2 also presented a high incidence of pathological manifestations by fungi in both periods. It is important to remind that this is the only one of the three buildings that does not have a high cellar, which means the ground floor does not have a source of ascending humidity. In Casarão 6, pathological manifestations were only registered during winter and in Casarão 8 no filamentous fungi were found.

For the weekday analysis, it is possible to say that, in environments used as exhibition rooms, the behavior of the temperature and relative humidity parameters was equivalent in the three buildings. In other words, the modus operandi in the three of them is similar, with little lighting and natural ventilation and few sources of internal humidity, due to the usage as exhibition rooms and to the fact that the building is closed. Although they are equivalent, the incidence of pathological manifestations by filamentous fungi occurred more intensively in House 2, the only one without a high cellar. In Casarão 6, fungi were only registered in winter, which means, after a long period closed. In Mansion 8, even though it was being used the same way as Number 2, no pathological manifestations by filamentous fungi were found, so it is related to the high cellar.

On the other hand, environments used for 
administration offices did not present the same equivalence and Casarão 2 was the one with the most different curves. Though they are different regarding thermal and hygroscopic behavior, since natural ventilation and solar radiation are controlled in different ways by users of Houses 2 and 8, there is low incidence of pathological manifestations in the first one and none in the second. Casarão 6, that was closed, presented the same behavior of the ground floor, with appearance of filamentous fungi only in winter.

This way, it is possible to verify the influence of natural ventilation and lighting in the appearance of pathological manifestations by filamentous fungi.

\subsection{Analysis of Results on a Weekend Day}

In administration offices usage, in a weekend day in summer, as shown in Table 8, temperatures began to rise in early afternoon, later than on weekdays. This occurs due to the fact that the buildings are not being used and thus are not under the influence of internal load, which contributes to the increase of temperature values. In winter, as seen in Table 9, temperatures did not present great variation.

Since the three buildings are closed and present the same construction characteristics, behavior should be similar. That was confirmed during summer, when temperature and relative humidity curves were equivalent and values were close. However, in winter, Casarão 2 presented higher temperatures (Figs. 13 and 14) and lower relative humidity levels (Figs. 15 and 16), differing from the others.

In the exhibition room usage, behavior was similar to administration offices in both seasons, as seen in Tables 10 and 11. That is because the three buildings presented the same conditions of use for the ground floors, too. Nonetheless, in this use, temperature (Figs. 17 and 18) and relative humidity (Figs. 19 and 20) remained close and equivalent also during summer, in the three buildings.

From analysis in a weekend day, it was possible to verify that the behavior of the three buildings is quite similar, both as exhibition rooms and as administration offices. That is, with the lack of natural ventilation and lighting, and without internal sources of humidity, values of temperature and relative humidity get very close.

Table 8 Results for a weekend day in summer in administration usage—qualitative analysis.

\begin{tabular}{llll}
\hline Variables & Casarão 2 & Casarão 6 & Casarão 8 \\
\hline Natural ventilation & Inexistent & Inexistent & Inexistent \\
Air temperature & Equivalent & Equivalent & Equivalent \\
Relative humidity & Higher & Intermediate & Intermediate \\
Humidity sources & Inexistent & Inexistent & Inexistent \\
Ascending humidity & Inexistent & Inexistent & Inexistent \\
Solar radiation & Inexistent & Inexistent & Inexistent \\
Pathological manifestations by filamentous fungi & Reduced & Inexistent & Inexistent \\
\hline
\end{tabular}

Table 9 Results for a weekend day in winter in administration usage-qualitative analysis.

\begin{tabular}{llll}
\hline Variables & Casarão 2 & Casarão 6 & Casarão 8 \\
\hline Natural ventilation & Inexistent & Inexistent & Inexistent \\
Air temperature & Higher & Lower & Intermediate \\
Relative humidity & Lower & Higher & Intermediate \\
Humidity sources & Inexistent & Inexistent & Inexistent \\
Ascending humidity & Inexistent & Inexistent & Inexistent \\
Solar radiation & Inexistent & Inexistent & Inexistent \\
Pathological manifestations by filamentous fungi & Lower & Higher & Inexistent \\
\hline
\end{tabular}




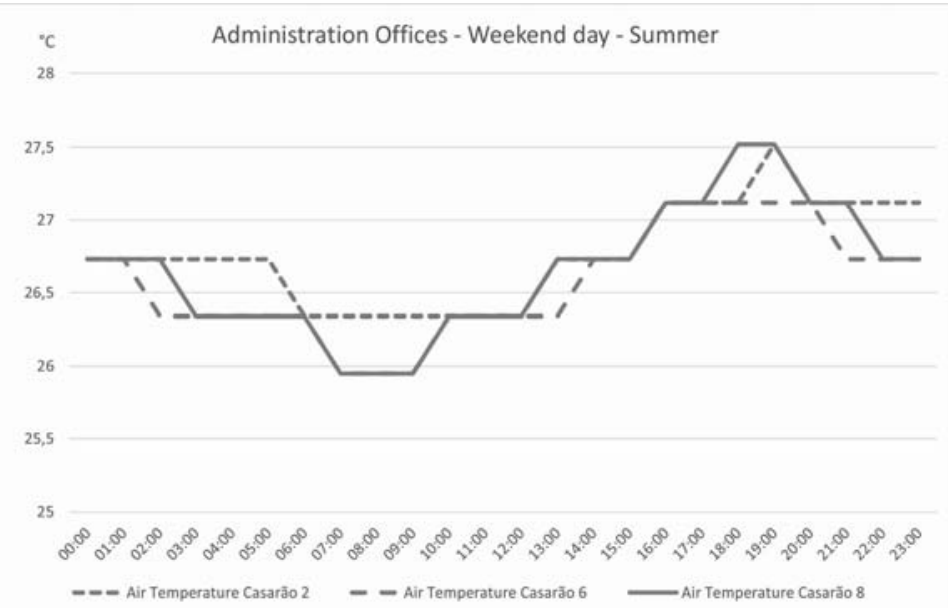

Fig. 13 Thermal behavior on a summer weekend day—administration offices. Source: the authors.

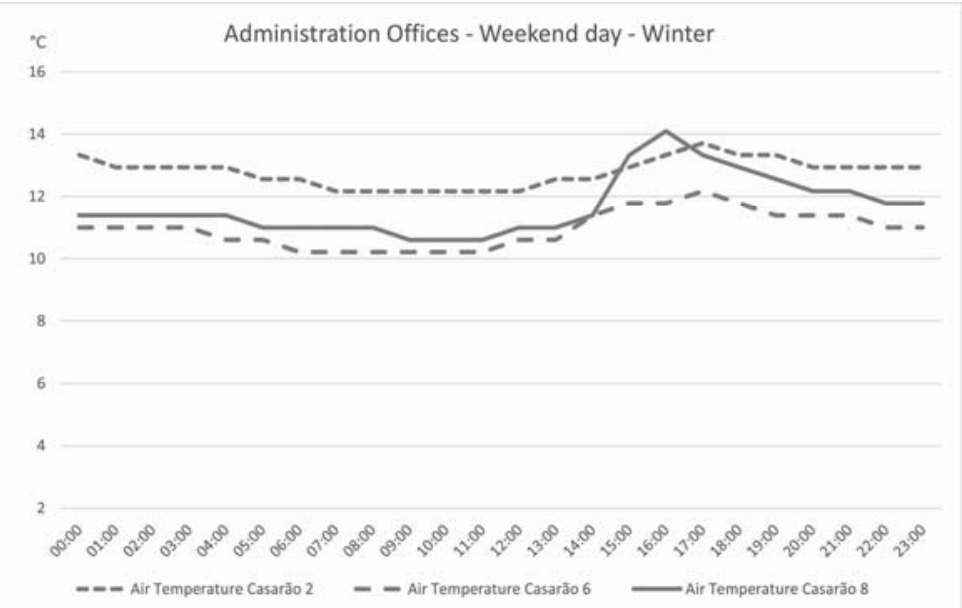

Fig. 14 Thermal behavior on a winter weekend day-administration offices. Source: the authors.

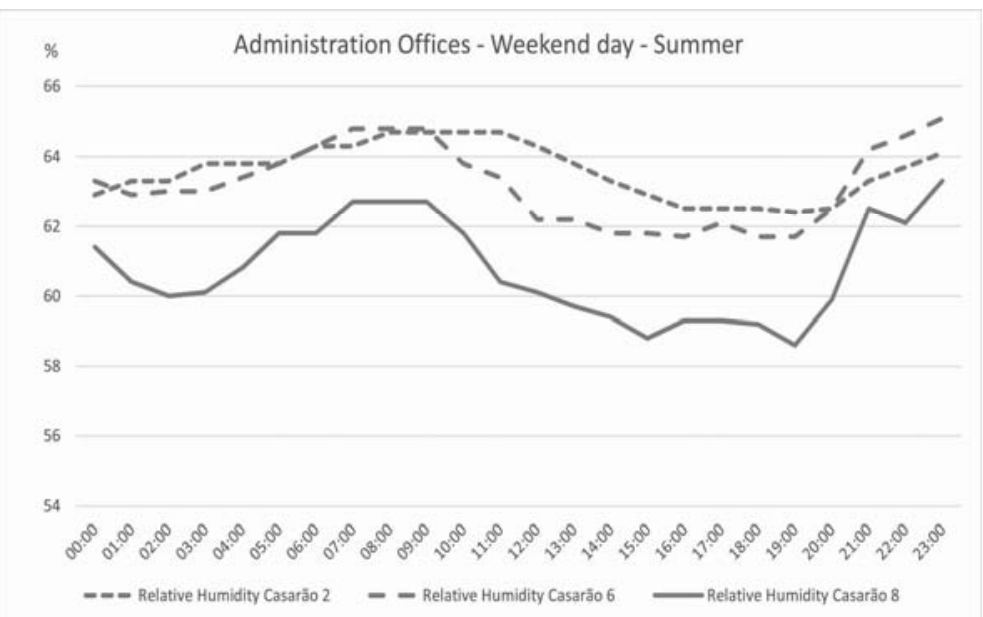

Fig. 15 Hygroscopic behavior on a summer weekend day-administration offices.

Source: the authors. 


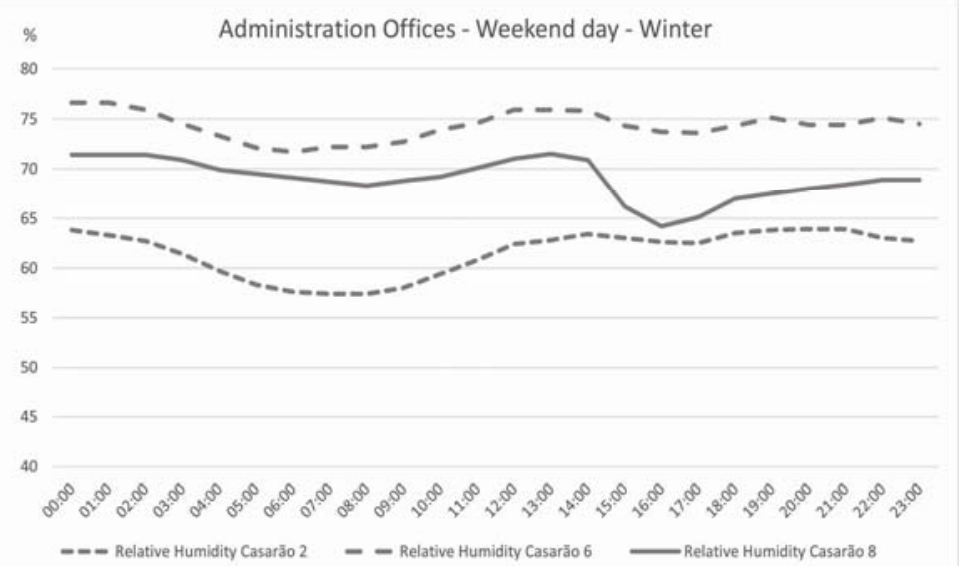

Fig. 16 Hygroscopic behavior on a winter weekend day-administration offices.

Source: the authors.

Table 10 Results for a weekend day in summer in exhibition room usage-qualitative analysis.

\begin{tabular}{llll}
\hline Variables & Casarão 2 & Casarão 6 & Casarão 8 \\
\hline Natural ventilation & Inexistent & Inexistent & Inexistent \\
Air temperature & Equivalent & Lower & Equivalent \\
Relative humidity & Higher & Intermediate & Lower \\
Humidity sources & Inexistent & Inexistent & Inexistent \\
Ascending humidity & Existent & Inexistent & Inexistent \\
Solar radiation & Inexistent & Inexistent & Inexistent \\
Pathological manifestations by filamentous fungi & High & Inexistent & Inexistent \\
\hline
\end{tabular}

Table 11 Results for a weekend day in winter in exhibition room usage—qualitative analysis.

\begin{tabular}{llll}
\hline Variables & Casarão 2 & Casarão 6 & Casarão 8 \\
\hline Natural ventilation & Inexistent & Inexistent & Inexistent \\
Air temperature & Higher & Lower & Intermediate \\
Relative humidity & Lower & Higher & Intermediate \\
Humidity sources & Inexistent & Inexistent & Inexistent \\
Ascending humidity & Existent & Inexistent & Inexistent \\
Solar radiation & Inexistent & Inexistent & Inexistent \\
Pathological manifestations by filamentous fungi & Higher & Lower & Inexistent \\
\hline
\end{tabular}

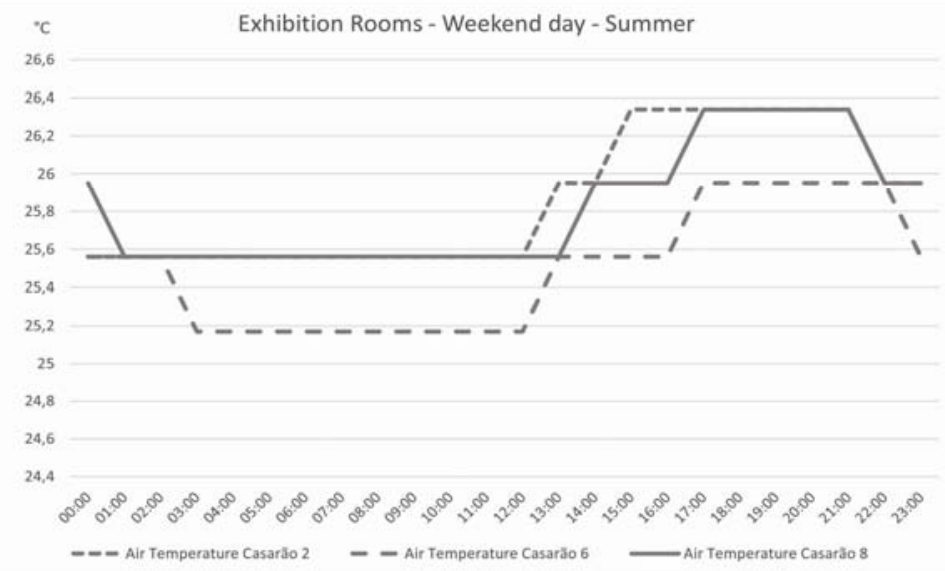

Fig. 17 Thermal behavior on a summer weekend day-exhibition rooms.

Source: the authors. 


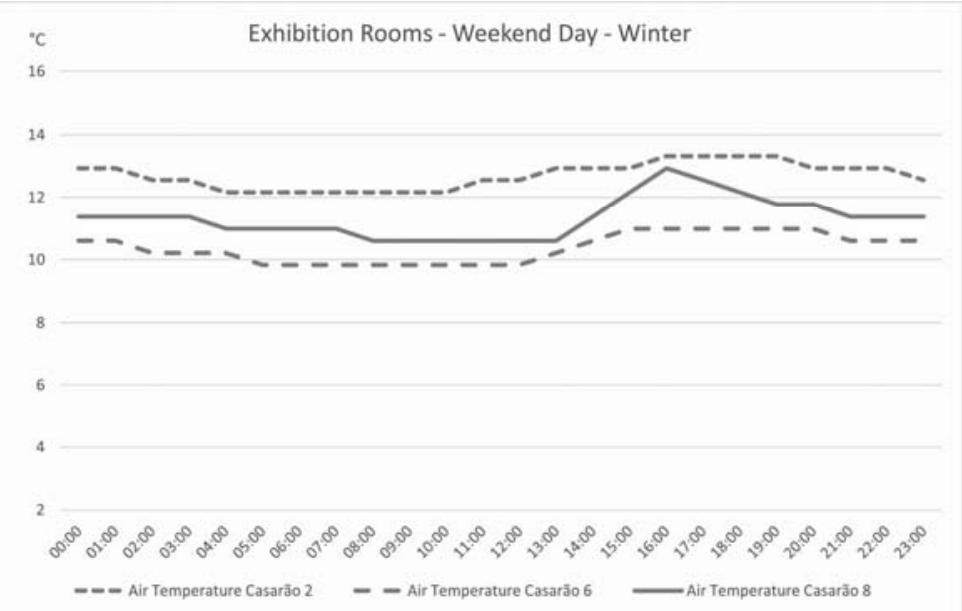

Fig. 18 Thermal behavior on a winter weekend day-exhibition rooms.

Source: the authors.

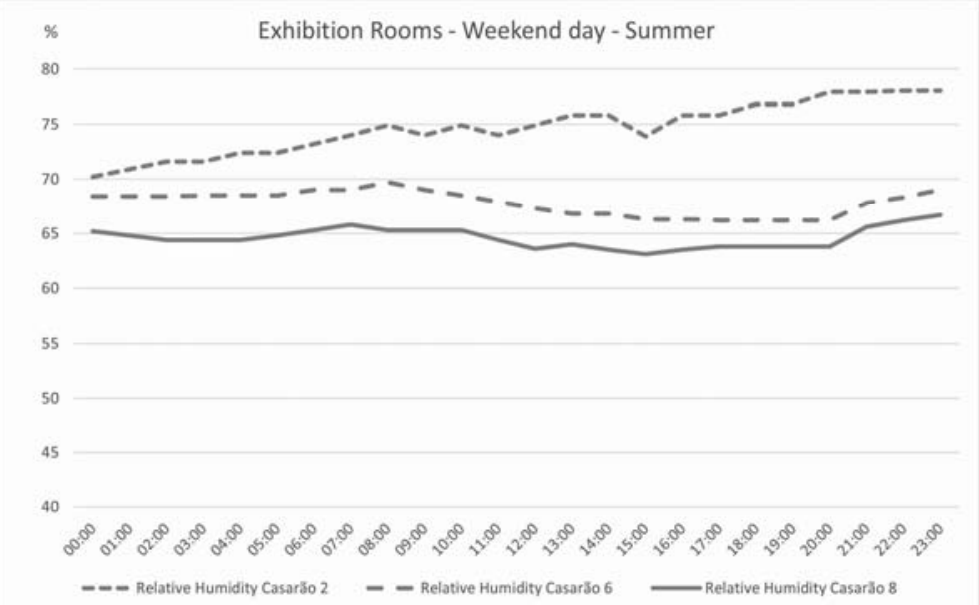

Fig. 19 Hygroscopic behavior on a summer weekend day-exhibition rooms. Source: the authors.

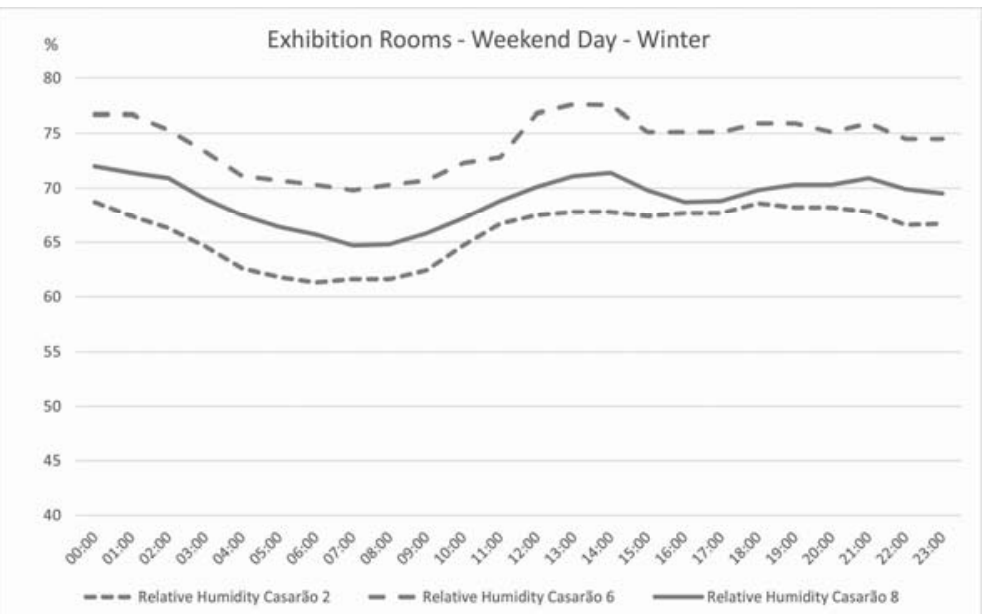

Fig. 20 Hygroscopic behavior on a winter weekend day-exhibition rooms.

Source: the authors. 


\section{Conclusions}

The goal of the research was achieved, since microclimate of historical buildings was characterized for different usages. It was noticed that new usages modify temperature and relative humidity levels, due to the existence of natural ventilation and lighting. Other than this, construction system has great responsibility for the internal conditions, regarding the environmental parameters that were analyzed.

So, it is possible to say that the use of a building, along with natural ventilation and with the presence of solar radiation, can assure conservation aspects when they have high cellars. That means this construction system blocks the presence of ascending humidity sources and contribute to avoid formation of filamentous fungi inside the buildings.

We also concluded that for buildings without a high cellar, it is extremely important that there should be incidence of natural lighting and ventilation in the environments. That is because ascending humidity favors appearance of pathological manifestations by filamentous fungi. So, new usages which stop ventilation and solar radiation are not recommended.

Using artificial climatization to achieve and keep relative humidity levels around 55\% would be the ideal way to fight the appearance of pathological manifestation by filamentous fungi. However, for this, new studies would be necessary, about pathological manifestations that may come from such change, such as cracks, for example.

It is important to mention that our sample is restrict, with only three buildings and two solar orientations and specific in the climate of Pelotas. Besides that, it is possible to say that this work contributes for aspects of conservation of historical buildings related to new usages.

\section{References}

[1] Jacobs, J. 2009. Morte e vida de Grandes Cidades (Life and Death of Big Cities). São Paulo: WMFMartins Fontes. (in Portuguese)
[2] Meira, A. L. G. 2008. “O Patrimônio Histórico e Artístico Nacional no Rio Grande do Sul no Século XX: Atribuição de Valores e Critérios de Intervenção (National Historic and Artistic Heritage in Rio Grande do Sul in the 20th Century: Assignment of Values and Intervention Criteria).” Dr. thesis, Federal University of Rio Grande do Sul, Porto Alegre. (in Portuguese)

[3] Secretaria Municipal de Cultura (City Department of Culture). 2008. Manual do Usuário (User Manual). 1st ed. Pelotas: Nova Prova. (in Portuguese)

[4] Camuffo, D., Pagan, E., Bernardi, A., and Becherini, F. 2004. "The Impact of Heating, Lighting and People in Re-using Historical Buildings: A Case Study.” Journal of Cultural Heritage 5: 409-16.

[5] Silva, H. E., and Henriques, F. M. A. 2014. "Microclimatic Analysis of Historic Buildings: A New Methodology for Temperate Climates." Building and Environment 82: 381-7.

[6] Aykal, D., Gümüs, B., Ünver, R., and Murt, Ö. 2011. “An Approach to the Evaluation of Re-functioned Historical Buildings in View of Natural Lighting: A Case Study in Diyarbakir Turkey.” Light and Engineering 19 (2): 64-76.

[7] Guerra, F. L., Peres, R. M., Cunha, E. G., and Galli, F. 2015. "Analysis of the Microclimate in Historical Building to Assess the Probability of Recurrence of Filamentous Fungi.” In Proceedings of International Symposium on Building Pathology.

[8] Balaras, C. A., Droutsa, K., Dascalaki, E., and Kontoyiannidis, S. 2004. "Deterioration of European Apartment Buildings." Building and Environment 37: 515-27.

[9] Lichtenstein, N. B. 1986. Patologia das Construções-Procedimentos para Diagnóstico e Recuperação (Constructions Pathologies-Procedures for Diagnosis and Recovery). Technical Bulletin. São Paulo: Civil Construction Engineering Department at EPUSP. (in Portuguese)

[10] Peres, R. M. 2001. "Levantamento e Identificação de Manifestações Patológicas em Prédio Histórico-Estudo de Caso (Survey and Identification of Pathological Manifestations in Historical Building-Case Study)." Master thesis, Federal University of Rio Grande do Sul, Porto Alegre. (in Portuguese)

[11] Lersch, I. M. 2003. "Contribuição para a Identificação dos Principais Fatores e Mecanismos de Degradação em Edificações do Patrimônio Cultural de Porto Alegre (Contribution for Identification of the Main Factors and Mechanisms of Degradation in Cultural Heritage Buildings in Porto Alegre)." Master thesis, Federal University of Rio Grande do Sul, Porto Alegre. (in Portuguese)

[12] Braga, M. 2003. Conservação e Restauro: Arquitetura. 
(Conservation and Restoration: Architecture). Book 03. Rio de Janeiro: Ed. Rio. (in Portuguese)

[13] Lourenço, P. B., Luso, E., and Almeida, M. G. 2006. "Defects and Moisture Problems in Buildings from Historical City Centres: A Case Study in Portugal.” Building and Environment 41: 223-34.

[14] Empresa Brasileira de Pesquisa Agropecuária (Brazilian Agricultural Research Corporation). 2016. Normais Climatológicas (Climatological Standards) 1971-2000. Accessed December 1, 2016. http://agromet.cpact.embrapa.br/estacao/normais.html. (in Portuguese)

[15] Pavlogeorgatos, G. 2003. "Environmental Parameters in Museums.” Building and Environment 38: 1457-62.

[16] Mendes, I. M. M. 2013. "Boas Práticas a Desenvolver em fase de Projecto de Arquitectura para Adaptação de Edifícios Existentes a Museus (Good Practices to be
Developed in the Architecture Project Stage for Adapting Existent Buildings into Museums)." Master thesis, University of Lisbon, Lisbon. (in Portuguese)

[17] Sedlbauer, K. 2001. Prediction of Mould Fungus Formation on the Surface of and Inside Building Components. Holzkirchen: Fraunhofer Institute for Building Physics.

[18] Guerra, F. L., Cunha, E. G., Silva, A. C. S. B., and Knop, S. 2012. "Análise das Condições Favoráveis à Formação de Bolor em Edificação Histórica de Pelotas, RS, Brasil (Analysis on the Favorable Conditions for Mold Formation in a Historical Building in Pelotas, RS, Brazil).” Ambiente Construído (Built Environment) 12 (4): 7-23. (in Portuguese)

[19] Sterflinger, K. 2010. "Fungi: Their Role in Deterioration on Cultural Heritage.” Fungal Biology Reviews 24: 46-55. 